Journal of Tropical Ecology

http://journals.cambridge.org/TRO

Additional services for Journal of Tropical Ecology:

Email alerts: Click here

Subscriptions: Click here

Commercial reprints: Click here

Terms of use : $\underline{\text { Click here }}$

\title{
Responses of leaf-litter ant communities to tropical forest wildfires vary with season
}

Juliana M. Silveira, Jos Barlow, Rafael B. Andrade, Luiz A. M. Mestre, Sébastien Lacau and Mark A. Cochrane

Journal of Tropical Ecology / Volume 28 / Issue 05 / September 2012, pp 515 - 518

DOI: 10.1017/S026646741200051X, Published online: 29 August 2012

Link to this article: http://journals.cambridge.org/abstract S026646741200051X

How to cite this article:

Juliana M. Silveira, Jos Barlow, Rafael B. Andrade, Luiz A. M. Mestre, Sébastien Lacau and Mark A. Cochrane (2012).

Responses of leaf-litter ant communities to tropical forest wildfires vary with season. Journal of Tropical Ecology, 28, pp 515-518 doi:10.1017/S026646741200051X

Request Permissions : $\underline{\text { Click here }}$ 


\title{
SHORT COMMUNICATION
}

\section{Responses of leaf-litter ant communities to tropical forest wildfires vary with season}

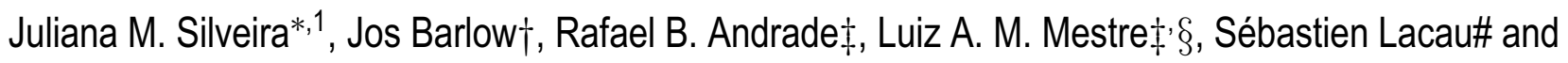 \\ Mark A. Cochrane $\ddagger$
}

\author{
* Universidade Federal de Lavras - UFLA, Caixa Postal 3037, Cep: 37200-000, Lavras, Minas Gerais, Brasil \\ $\dagger$ Lancaster Environment Centre, Lancaster University, Lancaster LA1 4YQ, UK \\ $\ddagger$ South Dakota State University, Brookings-SD 57007, USA \\ $\S$ Universidade Federal do Paraná, Palotina-PR 85950-000, Brazil \\ \#Universidade Estadual do Sudoeste da Bahia, Itapetinga-BA, 45700-000, Brazil \\ (Accepted 19 July 2012)
}

Key Words: Amazon, ant diversity, Brazil, community structure, disturbances, Formicidae, Mato Grosso, multidimensional scaling, tropical forest, Winkler funnels

Fire is an important land-management tool in tropical forest landscapes. However, these fires sometimes escape into surrounding forests (Uhl \& Buschbacker 1985), and are one of the most severe disturbances threatening tropical forest biodiversity (Barlow et al. 2006). These forest fires have become more frequent over the last decades due to the combined effect of selective logging, fragmentation and abnormal droughts that increase the flammability of forests, and agriculture expansion that brings the ignition sources (Aragão \& Shimabukuro 2010).

Despite the frequency and extent of Amazonian wildfires, our knowledge of their effects on tropical forest diversity is limited as existing studies are from relatively few locations and have focused mainly on vertebrates (Barlow \& Silveira 2009). Invertebrates are extremely important for tropical forests, and diverse and abundant taxa such as ants make an important contribution to a number of ecological processes such as organic matter decomposition, seed dispersal and predation, and the control of other invertebrate taxa. Although there are a small number of studies on ants within humid tropical biomes, none took place in closed-canopy forests (Castaño-Meneses \& Palacios-Vargas 2003, Vasconcelos et al. 2008).

We address this lack of knowledge by investigating the responses of ant communities to wildfires in a

\footnotetext{
${ }^{1}$ Corresponding author. Email: silveira.juli@gmail.com
}

seasonally dry forest at the southern edge of the Amazon. A growing body of literature suggests that insect biodiversity assessments could be strongly influenced by seasonality in tropical forests (Akutso et al. 2007, Barlow et al. 2007, Hamer et al. 2005, Hill et al. 2003, Silveira et al. 2010), and we evaluate how these seasonal differences affect commonly used metrics of diversity (species richness and species composition) and community-environment relationships after wildfires. Specifically, we tested the hypotheses that evaluations of the impact of wildfires on ants will be influenced by sampling in different seasons, affecting (1) estimates of species richness and species composition and (2) community-environment relationships, focusing on the established link between the volume of leaf litter on the forest floor and species richness.

The study was carried in 650 ha of native Amazonian forest in São Luiz Farm $\left(12^{\circ} 39^{\prime} 84^{\prime \prime} \mathrm{S}, 52^{\circ} 22^{\prime} 18^{\prime \prime} \mathrm{W}\right)$, municipality of Querência, in the state of Mato Grosso. These seasonally dry transitional forests are particularly vulnerable to wildfires as they have a very marked dry season (Balch et al. 2008) and have been fragmented by the expansion of cattle ranching and mechanized agriculture over the last $30 \mathrm{y}$.

In October 2007, part of the intact forest was burned by a wildfire during an extended dry season. We sampled an adjacent area of unburned forest that the local farmer protected from fire as our control treatment. Field data 
were collected once in the dry season (July 2008, 8 mo after the fire) and once in the rainy season (February 2009, 14 mo after the fire). As in many studies of its kind, time since fire is inevitably confounded with season, and more inter-annual replicates would be needed to confirm the findings of this study.

We sampled the ants and the forest structure in four transects in burned forest and three transects in unburned control forest. Transects were $500 \mathrm{~m}$ in length and were marked at four sampling points $150 \mathrm{~m}$ apart (at $50 \mathrm{~m}$, $200 \mathrm{~m}, 350 \mathrm{~m}$ and $500 \mathrm{~m}$ ). Transects were also placed $500 \mathrm{~m}$ apart from each other, so they could be considered independent sample units. Although the sampling design is spatially limited, taking place in two fragments of approximately $21 \mathrm{~km}^{2}$, it represents the highly fragmented local landscape where there is little intact forest cover remaining.

We collected ants using the Winkler funnel method. At each of the four sampling points we placed four $0.25-\mathrm{m}^{2}$ quadrats, $3 \mathrm{~m}$ apart from each other. Leaf litter inside each quadrat was removed, sieved (mesh $=1 \mathrm{~cm}^{2}$ ) to remove large debris and leaves, and combined into a single sample, totalling four points per transect. Fine material was kept in Winkler funnels in the shade for $3 \mathrm{~d}$ $(72 \mathrm{~h})$. Ants in the sieved fine material migrated out of the mesh bags inside Winkler funnels and were collected in a receptacle tied to the bottom, which was filled with a solution of $70 \%$ alcohol and a few drops of detergent. In the laboratory, ants were sorted and identified by an expert ant taxonomist (S. Lacau). Voucher specimens are stored at the Universidade Estadual do Sudoeste da BahiaUESB, Itapetinga, Bahia, Brazil.

As a previous study had found a link between the amount of leaf litter available on the forest floor and the number of leaf-litter ants (Vasconcelos et al. 2009), we estimated the leaf-litter volume of each quadrat where the ants were collected. Before sieving to removing large debris, we estimated the percentage of a $26 \times 28$-cm cylinder that was occupied by leaf litter. In order to evaluate fire severity in the same points where the ants were collected, we took $120^{\circ}$ hemispherical photographs which recorded canopy openness (linked to tree mortality). We also evaluated fire intensity by measuring the char height on the trees in an area of $500 \times 10 \mathrm{~m}$ alongside all burned transects. We checked for data distribution using Kolmogorov-Smirnoff test and applied parametric tests when possible. We used two-way Analyses of Deviance using chi-square to test the influence of season and treatment on local ant species richness, based on Poisson error structure appropriate for count data, and a log link. This was conducted in $\mathrm{R}$ version 2.14.0. Community structure was analysed based on the Bray-Curtis similarity index using multidimensional scaling (MDS) to ordinate samples based on presence-absence information. This was undertaken in Primer v.5. An analysis of similarity (ANOSIM) was used to test for significant differences in community structure between treatments.

Canopy openness was analysed using the Gap Light Analyzer program. Mann-Whitney tests were used to test for differences in canopy openness, as well as in leaf-litter volume between control and burned forest. We tested the relationship between leaf-litter volume and ant species richness using simple linear regression $(\mathrm{y}=$ $\alpha+\beta \mathrm{x}+e$ ). All tests were conducted using transects as sample units, except for the analysis of deviance and linear regressions where we used point data as we were interested in community-environment relationships at the smallest spatial scale.

Ant diversity was highly variable across treatments and seasons. In the dry season we collected 29 species in control forest and nine species in burned forest. In the rainy season 64 species were collected in control forest and 23 species in burned forest. There were significant differences in ant species richness between seasons and treatments at the scale of the sampling point. In the dry season, both treatments presented lower species richness per point compared with the rainy season, but the control forests presented more than four times more species than the burned forest (median $=4.5$, Interquartile range $(\mathrm{IQR})=3$; median $=1$, IQR $=0$, respectively). Species richness per point increased in both treatments in the rainy season and remained consistently higher in the control forest $($ median $=11.5, \mathrm{IQR}=8$; median $=3$, $\mathrm{IQR}=2$ respectively). The analysis of deviance using chi-square based on Poisson error distribution showed a significant effect of treatment $(\mathrm{P}<0.001)$ and season $(\mathrm{P}<$ 0.001 ), but no interactions between season $\times$ treatment $(\mathrm{P}=0.50)$ on species richness per sampling point.

Although ant communities in unburned and control forests were visually distinct in MDS ordinations in both seasons, these differences were only significant for the rainy season (Anosim tests, dry season: $R=0.31$, $\mathrm{P}=0.01$; rainy season: $\mathrm{R}=0.59, \mathrm{P}=0.05$; Figure 1 ). Ant communities in control forest were not affected by seasonality $(\mathrm{P}=0.15)$.

The wildfire had a strong negative effect on leaf-litter volume in burned forest. Eight months after fire, in the dry season, the leaf-litter volume in control forest (median = $4.27 \mathrm{~m}^{3} \mathrm{~m}^{-2}$, IQR $=2.41 \mathrm{~m}^{3} \mathrm{~m}^{-2}$ ) was more than double that in burned forest (median $=2.14$ units, $\mathrm{IQR}=$ 2.53 units; Mann-Whitney $\mathrm{U}=182, \mathrm{P}<0.001$ ). This difference was somewhat reduced 14 mo after fire (in the wet season) but the control forest still had higher leaflitter volume $\left(\right.$ median $=3.25 \mathrm{~m}^{3} \mathrm{~m}^{-2}, \mathrm{IQR}=2.97 \mathrm{~m}^{3}$ $\mathrm{m}^{-2}$ ) compared with the burned forest (median $=2.42 \mathrm{~m}^{3}$ $\mathrm{m}^{-2}$, IQR $=4.46 \mathrm{~m}^{3} \mathrm{~m}^{-2}$; Mann-Whitney $\mathrm{U}=146, \mathrm{P}=$ 0.02). Canopy openness was higher in the burned forest (median: 36.5\%, IQR: 29.5\%) compared with control forest (median: 18.1\%, IQR: 15.0\%; Mann-Whitney U = $0.00 ; \mathrm{P}=0.02)$. A total of 1467 trees were sampled in 


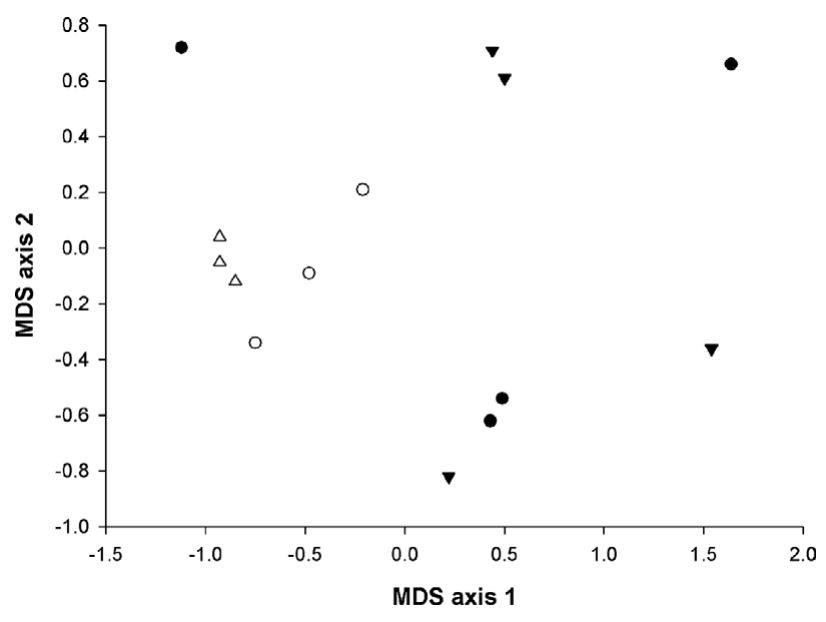

Figure 1. Multidimensional scaling (MDS) ordination for ant communities sampled in unburned control forests (open), once-burned forests (closed), in dry season (circles) and rainy season (triangles), in Mato Grosso, Brazilian Amazonia.

the burned transects, and $46.1 \%$ of them showed some kind of fire scar on their stems, with $4.7 \%$ of stems being charred higher than $1.3 \mathrm{~m}$ in height.

During the dry season, relationships between local ant species richness and leaf-litter volume were not significant $\left(\mathrm{R}^{2}=0.03, \mathrm{~F}_{1,12}=1.35, \mathrm{P}=0.27\right.$ and $\mathrm{R}^{2}<0.001$, $\mathrm{F}_{1,10}=0.74, \mathrm{P}=0.41$ for unburned and burned forest, respectively). However, rainy-season ant species richness per point was positively related to leaf-litter volume in unburned and burned forest, respectively $\left(\mathrm{R}^{2}=0.31\right.$, $\mathrm{F}_{1,12}=5.96, \mathrm{P}=0.04$ and $\mathrm{R}^{2}=0.58, \mathrm{~F}_{1,10}=15.9$, $\mathrm{P}<0.01$, Figure 2). The linearity of this relationship was supported by the random distribution of residuals, and by the skew value calculated being less than 2 SE.

We provide the first comparison of ant community responses to wildfires in closed-canopy humid tropical forests, and found that (1) both season and burn treatment influenced patterns of ant species richness and composition; (2) the strength and significance of community-environment relationships were dependent on the season that ants were sampled in.

Comparisons of species richness are heavily influenced by spatial scale at which the comparison is made (Hamer \& Hill 2000). We examined how this is affected by seasonality, and show that findings based on measurements of total richness (rarefaction curves) are relatively robust to seasonality, as there was no difference between burned and unburned forest in either season. Species richness measured at the sample point corroborates the rarefaction curves, showing a similar pattern. In both cases the species richness in control forest in both seasons sampled was four or more times higher than the burned forest. These results are similar to those observed in regions with marked dry season like a burned forest in cerrado (Brazilian savanna) vegetation (Vasconcelos et al. 2009) and an agricultural
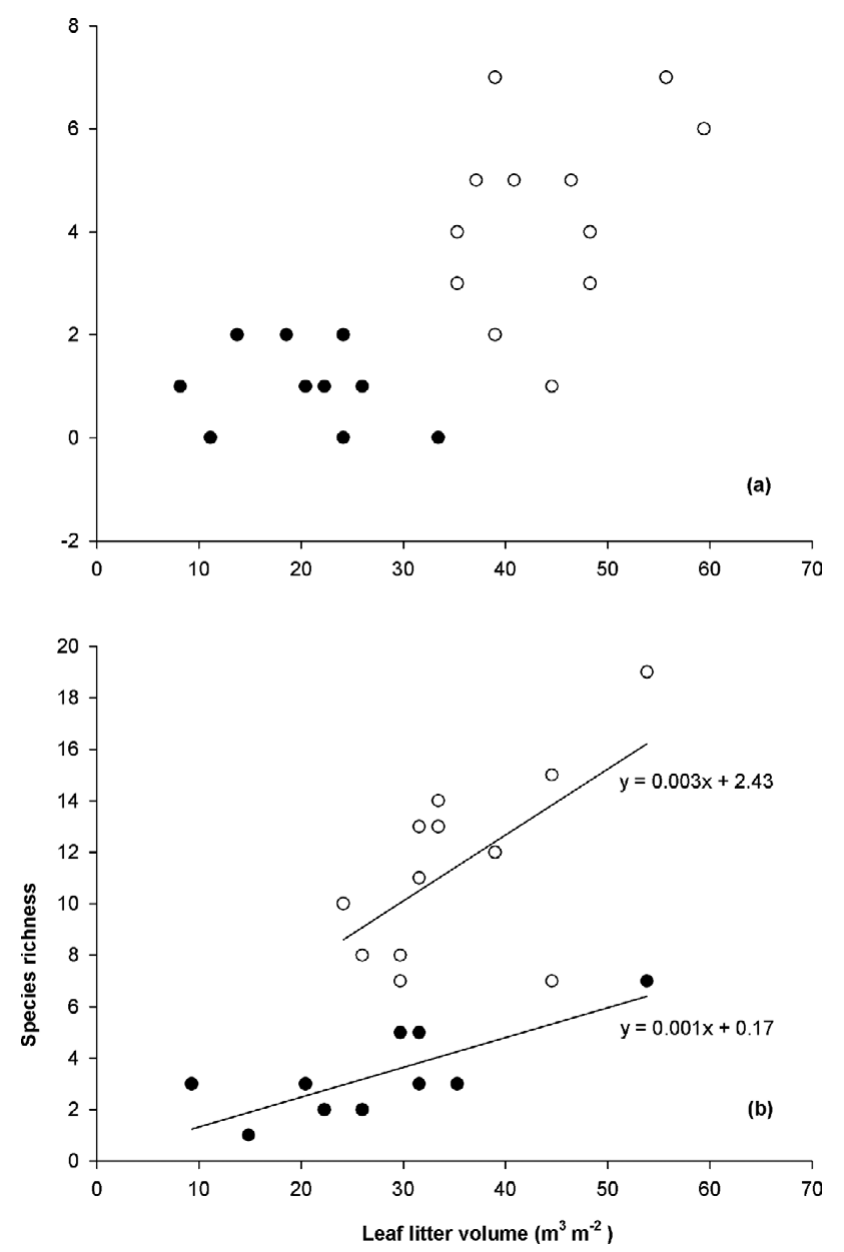

Figure 2. Linear regressions showing the response of ant species richness to variation in leaf-litter volume, in control (open circles) and burned forests (closed circles) and in the dry (a) and rainy (b) seasons, in Mato Grosso, Brazilian Amazonia.

landscape in a tropical dry forest in Mexico (HernándezRuiz \& Castaño-Meneses 2006). Marked changes in ant community composition between control and disturbed forests across seasons were previously reported in a gradient of secondary forests in Atlantic forest in Brazil (Neves et al. 2010), and in a 25-y-old secondary forest in Congo (Deblauwe \& Dekoninck 2007). In our study, community structure was changed after fire, but with significant results only for the rainy season, 14 mo after fire (Figure 2). We expected differences to be more pronounced in the more recent sampling after the fire ( 8 mo, dry season). Although this was graphically supported in the MDS (there was a clear separation between control and burned forests in the dry season, Figure 2), samples sizes were limited and the results of Anosim did not corroborate our expectations. We believe such difference could be statistically supported with an increasing of the sampling effort. Therefore, as differences between control forests in both seasons were not significant, we conclude that our results for ant communities are due to the wildfire effect but could also be influenced by seasonality. 
Previous studies have demonstrated a positive relationship between leaf litter and ant species richness (Vasconcelos et al. 2009). However, in our study, ant species richness was only significantly and positively related to the volume of leaf litter on the forest floor in the rainy season, 14 mo after fire. Perhaps these species-environment relationships are modified by the low numbers of ant occurrences in the dry season, the time required for recolonization, or issues relating to litter humidity. Whatever the reason, our results demonstrate that species-environment relationships can also be strongly influenced by seasonality and/or time since fire in tropical forests.

Our results suggest that fire can change leaf litter ant communities, but such effects become more evident during the rainy season when ant activity and capture rates are higher in the traps. Therefore, although sampling in the dry season may be logistically easier in many regions, researchers should be aware they are less likely to find an effect as ant activity is much lower. Given this, we propose that researchers replicate sampling in two seasons or invest in a higher sampling effort if restricting sampling to the dry seasons. Failure to do so risks underestimating the impact being investigated through Type I errors.

\section{ACKNOWLEDGEMENTS}

The lead author would like to acknowledge support from Fundação de Amparo à Pesquisa do Estado de Minas Gerais - FAPEMIG, who provided a postdoctoral fellowship. We are very thankful to Simar Nogueira for helping to search for suitable areas and to Luiz Pirani for giving permission to our research. This paper is part of the Biological Diversity Program of the Earth Science Division of the NASA Science Mission Directorate (NNX07AF16G), the UK National Environment Research Council grant (NE/G000816/1) and the Instituto Nacional de Ciência e Tecnologia Biodiversidade e Uso da Terra na Amazônia ( $\mathrm{CNPq}$ 574008/2008-0).

\section{LITERATURE CITED}

AKUTSO, K., CHEY, V. K. \& TODA, M. J. 2007. Assessment of higher insect taxa as bioindicators for different logging-disturbance regimes in lowland tropical rain forest in Sabah, Malaysia. Ecological Research 22:542-550.

ARAGÃO, L. E. O. C. \& SHIMABUKURO, Y. E. 2010. The incidence of fire in Amazonian forests with implications for REDD. Science 328:12751278.

BALCH, J. K., NEPSTAD, D., BRANDO, P. M., CURRAN, L. M., PORTELA, O. F., DE CARVALHO, O. \& LEFEBVRE, P. 2008. A negative fire feedback in a transitional forest of southeastern Amazonia. Global Change Biology 14:1-12.
BARLOW, J. \& SILVEIRA, J. M. 2009. The consequences of fire for the fauna of humid tropical forests. Pp. 543-556 in Cochrane, M. A. (ed.). Tropical fire ecology - climate change, land use and ecosystem dynamics. Springer, Berlin.

BARlOW, J., PERES, C. A., HENRIQUeS, L. M. P., STOUfFER, P. C. \& WUNDERLE, J. M. 2006. The responses of understorey birds to forest fragmentation, logging and wildfires: an Amazonian synthesis. Biological Conservation 128:182-192.

BARLOW, J., OVERAL, W. L., ARAÚJO, I. S., GARDNER, T. A. \& PERES, C. A. 2007. The value of primary, secondary and plantation forests for fruit-feeding butterflies in the Brazilian Amazon. Journal of Applied Ecology 44:1365-2664.

CASTAÑO-MENESES, G. \& PALACIOS-VARGAS, J. G. 2003. Effects of fire and agricultural practices on neotropical ant communities. Biodiversity and Conservation 12:1913-1919.

DEBLAUWE, I. \& DEKONINCK, W. 2007. Diversity and distribution of ground-dwelling ants in a lowland rainforest in southeast Cameroon. Insect Sociaux 54:334-342.

HAMER, K. C. \& Hill, J. K. 2000. Scale-dependent effects of habitat disturbance on species-richness in tropical forests. Conservation Biology 14:1435-1440.

HAMER, K. C., Hill, J. K., MUSTAFFA, N., BENEDICK, S., SHERRATT, T. N., CHEY, V. K. \& MARYATI, M. 2005. Temporal variation in abundance and diversity of butterflies in Bornean rain forests: opposite impacts of logging recorded in different seasons. Journal of Tropical Ecology 21:417-425.

HERNÁNDEZ-RUIZ, P. \& CASTAÑO-MENESES, G. 2006. Ants (Hymenoptera Formicidae) diversity agricultural ecosystems at Mezquita Valley, Hidalgo, Mexico. European Journal of Soil Biology 42:208-212.

HILL, J. K., HAMER,, K. C., DAWOOD, M. M., TANGAH, J. \& CHEY, V. K. 2003. Rainfall but not selective logging affect changes in abundance of a tropical forest butterfly in Sabah, Borneo. Journal of Tropical Ecology 19:35-42.

NEVES, F. S., BRAGA, R. F., DO ESPÍRITO-SANTO, M. M., DELABIE, J. H. C., FERNANDES, G. W. \& SÁNCHEZ-AZOFEITA, G. A. 2010. Diversity of arboreal ants in a Brazilian tropical dry forest: effects of seasonality and successional stages. Sociobiology 56:177-194.

SILVEIRA, J. M., BARLOW, J., LOUZADA, J. \& MOUTINHO, P. 2010. Factors affecting the abundance of leaf-litter arthropods in unburned and thrice-burned seasonally-dry Amazon forests. Plos One 5:e12877. http://www.plosone.org/article/info\%3Adoi\% 2F10.1371\%2Fjournal.pone.0012877

UHL, C. \& BUSCHBACHER, R. 1985. A disturbing synergism between cattle ranch, burning practices and selective tree harvesting in the eastern Amazon. Biotropica 17:265-268.

VASCONCELOS, H. L., LEITE, M. F., VILHENA, J. M. S., LIMA, A.P. \& MAGNUSSON, W. E. 2008. Ant diversity in an Amazonian savanna: relationship with vegetation structure, disturbance by fire and dominant ants. Austral Ecology 33:221-231.

VASCONCELOS, H. L., PACHECO, R., SILVA, R. C., VASCONCELOS, P. B., LOPES, C. T., COSTA, A. N. \& BRUNA, E. N. 2009. Dynamics of the leaf-litter arthropod fauna following fire in a Neotropical woodland savanna. Plos One 4:e7762. http://www.plosone.org/article/ info\%3Adoi\%2F10.1371\%2Fjournal.pone.0007762 